\title{
Public Communication and Power: Talking Capitalism, Theory and Critique with John McMurtry
}

\author{
Jeffery Klaehn*; Daniel Broudy**; John McMurtry*** \\ * Writer, Kitchener, Ontario, Canada, jklaehn@wlu.ca \\ ** Professor of Rhetoric and Applied Linguistics at Okinawa Christian University, \\ Japan, dbroudy@ocjc.ac.jp \\ *** Fellow of the Royal Society of Canada, University Professor and Professor of Phi- \\ losophy Emeritus, University of Guelph, Canada, mcmurtry@uoguelph.ca
}

\begin{abstract}
This interview with globally distinguished Canadian philosopher and author, John McMurtry, presents dialogue discussing capitalism, asymmetrical power relations, life capital, social theory, common life interest, life value, global problems, market theology, media, values of the market and free market ideology today in relation to public education, academia, intellectual fads and the broader intellectual culture in relation to enabling public understanding of meaning-making and power, totalising market culture, climate, dispossession, health, influence, energy, labour, income, slavery, corporate welfare, neo-liberalism, the global ecosystem, and inequalities of class and power.
\end{abstract}

Keywords: public communication, power, media, international political economy, social power, economic power, ideological power, capitalism, slavery, corporate hegemony, democracy, everyday life, life value, economics, health, public knowledge, education, sociology of intellectuals, social theory, public sphere, ideas, values, common good, civil commons, money, capital, labour, social class, technology, intellectual culture, academia, social agency, legitimations

\section{Introduction}

John McMurtry has been described as "the foremost social philosopher of our time"1 and his works have been translated into numerous languages across the globe. His published lectures, correspondence, articles and books - including this interview explore social conditions of everyday life, knowledge and the cultural realm, the environment and global ecosystem, and democracy in relation to domination, asymmetrical power relations and capitalist political economy, exploitation and class relations, and ideology. Centrally positioned within his works are questions about the meaning and future of health, happiness and the common good within a life-blind world system.

\section{Public Communication and Power}

Dan: As you have explained in "Money Value vs Life Value: The War of Values We Live or Die By" (McMurtry and Klaehn 2020), corporate capitalism everywhere demands private money value and sacrifices the life value and capital of nature, society and our bodies themselves to it. As this present system normalises destruction and

\footnotetext{
1 Jeff Noonan, author of Embodiment and the Meaning of Life (see Noonan, 2020); correspondence with Jeffery Klaehn, October 5, 2020.
} 
dispossession at every level, how do we mount an intellectual self-defence against it? How do we bring an alternative reality into view?

John: This problem seems insoluble until one recognises that our social evolution has developed underlying layers of collective life capital organisation not recognised in received economic, political and social theory. It begins with human language itself - the primary collective life capital of human society across generations. But it also includes all of society's unpriced life-carrying capacities including ecosystems participating in the collective life wealth and identity of the society - "the Earth is our mother" is a universal of tribal communities and environmentalists today. Yet there is no name for this common natural and social life ground of the human condition except civil commons.

Not "civil society" which is an aggregate of individual interests deriving from property holders or "stakeholders" with no collective ground. Not "social capital" which refers only to what reduces private money costs of market transactions. Not the reversal of the "commons" in Garrett Hardin's "Tragedy of the Commons" which is ignorant of the evolved rules of the traditional commons to protect the community's natural resources from market-driven ruin. Not "the commons" of Elinor Ostrom or "the social economy" of recent decades which are private formations excluding publicly funded programs since government is assumed as a Hobbesian monster. The civil commons, in contrast, go back to the village commons and tribal communities which enable universal but regulated access of the community to natural and social goods just as life-protective law, universal education and healthcare continue to do today.

The civil commons are not, however, Burkean customs and traditions because they are opposed in principle to cultural taboos or ruling-class norms disabling rather than enabling people's lives. As with language which leads their evolution, civil commons develop the more they are used - from norms of civility and mutual care to clean water sources and common pathways to universal life-security programs. In this conception, the "public realm" of Jane Jacobs and urban movements are underlying civil commons too insofar as they save long-evolved neighbourhoods and building heritages from big-city developers running highways and high-rises through them. This "social immune system" of the civil commons fights for defence of the universal life goods of society and nature inherited from prior generations. Or it leads to new civil commons from public sewers to playgrounds, libraries and green spaces for all, or energy and environmental regulations to mitigate climate destabilization and universal income support for the unemployed in the time of Covid-19.

The unseen tragedy is that these civil commons are blocked out of theory and practice across the contemporary world when most needed - when deregulated capitalism allows any violation of the common life bases of society and the expropriation of their public funding without categories to comprehend the collective dispossession. Pervasive noise, pollutions, draw-downs and wastes of the natural and social commons without correction are the predictable consequences, but are nullified by the ruling economics as "externalities." As first peoples' understanding attributed to Crowfoot puts it: "Only when the last tree has been cut down, only when the last river has been poisoned, only when the last fish has been caught will you realise you can't eat money".

Collective self-defence begins by the action of knowing this shared life capital base of the world and the common cause of its despoliation. It recognises that capitalist "efficiency" is only cost reduction in producing private commodities for profit, and that this driver systematically selects for no-cost looting and polluting of organic, 
social and ecological life systems. Yet private commodities for those who can pay for them hold the well-off in thrall even when the living world is despoiled - for example, ever more luxurious-power "sports vehicles" ripping up pristine environments as "freedom". In social-immune response of civil commons, first peoples' and environmentalists defend treaty and public lands and the climate of the world from cumulative fossil-fuel pollution and destruction by collective action in body, spirit and online. In short, the civil commons and their collective life capital base are not an "alternative reality" or an "imaginary". They are the underlying evolution of the human species at the crossroads of public recovery or private ruin (see McMurtry's book The Cancer Stage of Capitalism: From Crisis to Cure).

Jeff: If phrasings like "capital of nature," "life capital," and "life value" are used, doesn't this open the discourse to critique, for naturalising capitalism? Marx distinguished between the natural and social worlds. What are your thoughts on this?

John: Marx is certainly right in rejecting the naturalisation of capitalism - assuming it is an "eternal necessity" like the laws of nature or physics, which "Economics" is still modelled on. Even the real free market in a public place with producer control and no toxic commodity cycles is overrun behind this robotic assumption. But it is not economic "laws of motion" at work, but a life-blind mathematics of multiplying private money value extraction to the top. The concept of life capital is the very opposite. It is all individual, social and natural life capacities that produce more without loss and cumulative gain through generational time. Civil commons enable universal access to these life goods - from collective symbol systems to water and waste dividers to lifesecurity norms and infrastructures. They depend, as everything else, on natural life support systems underneath resource exploitation to which modern economic thought has been confined - from climate and hydrological cycles to the evolved biodiversity of the natural species. The shortfall of Marxism is that it has no categories to comprehend this civil commons and collective life capital base beneath class division. It also has no place for natural life carrying capacities organisation and species unmediated by human labour (see the essay "150 Years After Capital: Reading Marx as Life Grounded"; McMurtry 2017). This underlying common life-ground is blinkered out not only by Marx, but by all received modern theory. It is the fundamental life blindness of the epoch.

Jeff: You say almost all modern theory. Are there theoretical optics you're thinking of that do conceptualise life in this way?

John: Only life-value onto-axiology conceptualises in this way as developed in "What is Good? What is Bad? The Value of All Values across Time, Place and Theories" (McMurtry 2004a). Here and elsewhere, civil commons and collective life capital are the underlying objective substance of human evolution with the "social immune system" to protect them, but this is unseen and despoiled by private profitisation of all that exists. Without conception of these collective life foundations, they are hollowed out like a macro-cancer devouring its life host. All of this is post-Marxian in conception. Marx prioritises technological development with no life ground except the organised forces of production as the independent variable of history. "Nature is subjugated to human purpose" and products are "nothing but definite quantities of labour time". This is Marx's labour theory of value, his onto-axiology. 
There are post-1970 attempts to present Marx as an ecological thinker - James O'Connor to John Bellamy Foster, for example - who may seem to solve this problem since Marx was certainly aware of the despoliation of the soil and the human organism itself. But this cannot resolve his instrumentalist anthropocentrism in which no species or life carrying capacity has value independent of human use. In contrast, life-value onto-axiology and life capital measure values all life in itself in accordance with the "Primary Axiom of Value" as defined in Philosophy and World Problems.

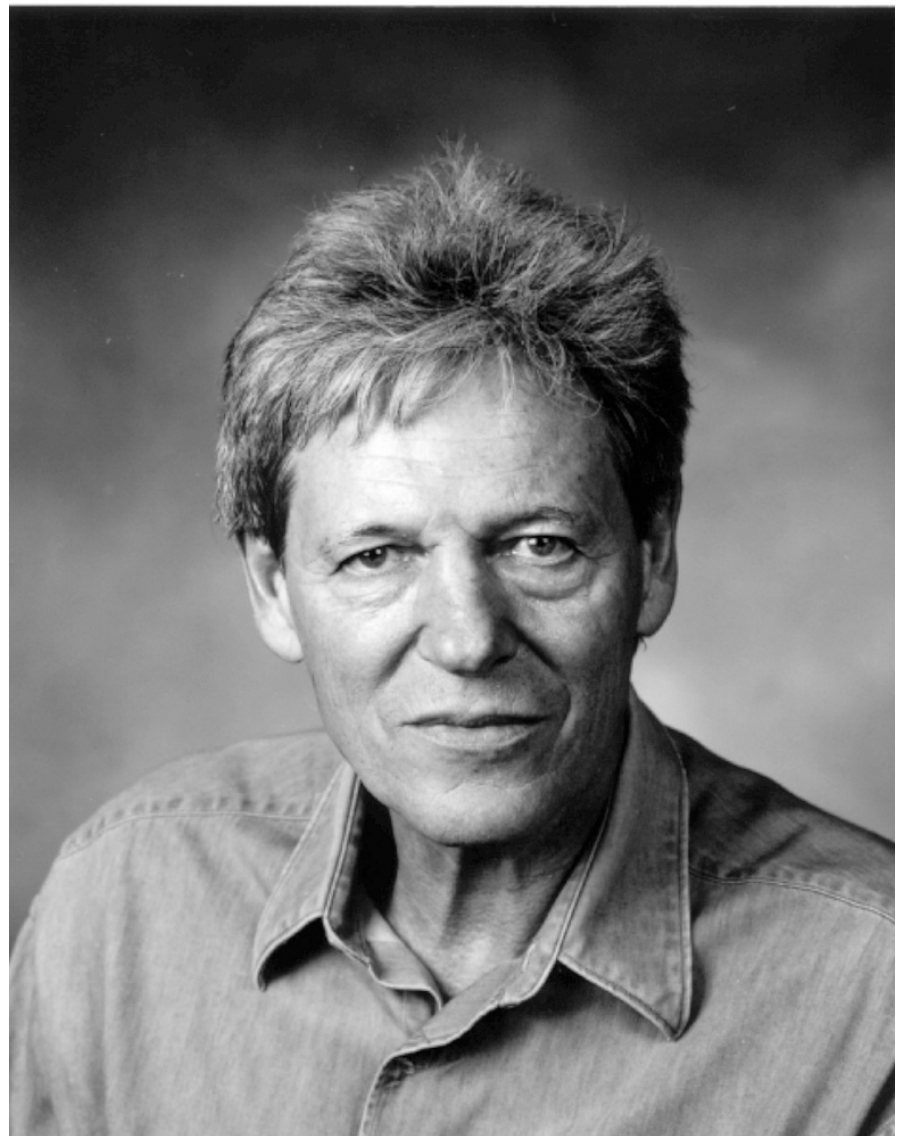

Jeff: What are your thoughts on corporate welfare today, John, and how does it connect back to media, ideology and values of the market, and on free market ideology today, as well, in relation to education and the broader intellectual culture? How is all reflective of inequalities of class and power - social, political, economic, ideological and how do these elements legitimise, perpetuate, and amplify these inequalities?

John: There are many questions here, but they all connect. "Corporate welfare" includes its subclass of "media," i.e., monopoly bandwidths, controlling access to state leaders, and corporate-news framing of public issues. More lethally, "corporate welfare" includes the licencing of endless new commodity cycles and sales despoiling our ecological, social and organic life support systems as our "freedom" - including planned breakdown of appliances and computers to cumulative waste and throw away valuable elements pillaged from evolved ecosystems. Then limited liability - the meaning of Ltd on corporate commodities - rules out suing the profit-making owners themselves.

A corporate-welfare taxation system then deprives the public of the revenues to do anything about it, with ruling political parties and elected officials daily pressure lobbied and financed to ensure compliance with the corporate agenda in motion - in 
truth, an institutionalised regime of corrupting influence with impunity. Most unspeakable in the corporate welfare system is the licence to Wall Street and big banks to print debt money at compound interest with no controls - including by governments themselves which have surrendered their constitutional right over currency issue. As Senator Dick Durbin said of Wall Street, "they pretty well run the place".

The most expensive corporate state institution is the US military that enforces and globalises this life-blind money system. It's called "Defence" and "national security" with no one publicly questioning the Orwellian language for the world's lead terrorist forces effectively operating above the law domestically and abroad. "Freedom" and "free market" is the legitimising ideology. Self-maximising gain is "rationality," and life necessities do not exist in scientific or business accounts (see "Behind Global System Collapse: The Life-Blind Structure of Economic Reality", McMurtry 2012). Every media of education and research as well as public communication assumes these first premises of reason and motive, and the illusions are perfected by "Economics" in mathematical symbols emptied of life meaning.

The world's near-richest man, Warren Buffet, may bravely and publicly say that "there is class warfare all right. But it is my class, the rich class, that is making war, and we are winning". But the words become an inoculation display against growing mistrust in the "free press", and deeper investigation is here and elsewhere labelled "conspiracy theory". Trump may be attacked by the legacy press for his failings, but not for his war against the common life interest - the greatest dispossession of the public realm in history to transfer trillions more to the corporate rich, and the most sweeping destruction ever of public lands and regulations for corporate polluting industries. None of this is called to account by party Democrats.

"Education and the broader intellectual culture" follow suit. Isolated issues avoiding causal structures have long occupied discussion. Celebrities, scandals, spectator sports, and rises and falls of private stock-markets are the perpetual "news" - with the latter always in the end rising with $90 \%$ of payoffs to those who manipulate it. Pervasive untruths and selected evidence are so built into market culture that the White House leads the country with them. The academy quietly conforms to the corporate agenda. What normally matters most is self-career by a narrow technical expertise which lands funding and promotions. Postmodern thinking pre-consciously imitates the commercial culture of self-desires and perspectives as all there is. Intellectual fads rule out system-critical understanding. All this is "reflective of inequalities of class and power - social, political, economic, ideological" and all of it "legitimises, perpetuates, and amplifies these inequalities". But mere "inequalities" are not the worst of it.

Jeff: Can you elaborate upon what you're saying here about intellectual fads ruling out system-critical understandings? Noam Chomsky has likened "the prevailing academic and broader intellectual culture" to "hegemonic culture in the Gramscian sense" (Chomsky, cited in Klaehn et al 2018, 166). Do you agree with this? In his 1967 text, The Responsibility of Intellectuals, Chomsky (1967) wrote that "it is the responsibility of intellectuals to speak the truth and to expose lies. This, at least, may seem enough of a truism to pass over without comment. Not so, however. For the modern intellectual, it is not at all obvious". Where are we now, in your view, especially in relation to public education and the big picture problems of power and powerlessness, and power imbalances in relation to dominant social institutions, the public sphere and legitimisations of power? 
John: In a nutshell, the "intellectual fads" are produced in reflection of a totalised market culture. In the academy and intelligentsia in general, major brands like Harvard set the fashion, and corporately-owned journals and books reproduce it. Underneath the fads are unspoken rules blocking critique of the ruling value system. This is the "big picture" of legitimating power by selecting out whatever calls it into question. Learned confrontation is dismissed as "extremist" or "unsophisticated," and methodologies demand exact framing within given parameters so that challenges of basic assumptions have no logical space. For meta example, the fixed preconception across the sciences is that rationality is self-maximising preference - as in economics, game theory, contract and incentive literatures, and evolutionary biology driven by the "selfish gene". All of this serves to make relations of "power and powerlessness" invisible in "the dominant institutions," including the academy. They are assumed as outcomes of competitive self-maximisation which is further assumed as natural and right. Analysis of the underlying syntax of such preconceptions as the "regulating group mind" explains the academy's conformity to the surrounding order of power across fads, cultures, and even epochs (Mills et al. 2010). It steers the works of even Socrates, Plato, and Aristotle who implicitly legitimate slaves and foreign invasion as necessary and good. John Locke, himself a prosperous investor in slavery, does much the same millennia later as the lead rationaliser of enclosure of the commons into private property, and rights of conquest abroad, all dressed in eloquent rhetoric repeated in the US Declaration of Independence.

The medieval philosophers before Locke into Descartes launch the modern era of scientific rationality and critical doubt, but never question the existence of God or Church dogmas or absolutist royal rule. Such deviations are a capital offense across Christendom and Islam for centuries, and still are in some places. In this way, there is an ancient taboo against "intellectual responsibility" at the deepest level. When scientific logic becomes the ruling norm, its received champions do not question the surrounding capitalist order or its foundational value assumptions. When Sartre turns from existentialist freedom to Marx and dialectical method to lay bare a "hierarchy of determinants" of choice, he is erased from academic study. Erich Fromm and Herbert Marcuse who ground in a life base for "Critical Theory" are dropped from academic conversation. Einstein who writes "Why Socialism" is condescended to as simple minded.

There is now even less "intellectual responsibility" to "speak the truth and expose lies" than when Chomsky's article was published in 1967. After the overthrow of Chile's elected government in 1973 following ignominious US retreat from Vietnam, death-squad dictatorships ruled Latin America and elsewhere, and the market fundamentalism of Hayek and Friedman came to dominate for decades with an underlying market theology (see "Understanding Market Theology", McMurtry 2004a). Postmodernism complements market fundamentalism with its corrosive cynicism about all other universal principles. "Marxism is dead" becomes a pervasive slogan, and "power and powerlessness" become more extreme. When capitalist power is democratically overturned in Latin America after 2000, as in Bolivia under a first-nations leader nationalising its natural resources, a continent-wide counter-revolution is orchestrated by 2013. Under false pretexts coups d'état are declared the "return of "democracy". When the lavishly subsidised billionaire Elon Musk is asked about the U.S. government organising the coup against Evo Morales so that he could obtain Bolivia's rare and valuable lithium fields, Musk tweets, "We will coup whoever we want! Deal with it". 
Today, Chomsky calls this big-lie rule "the neo-liberal plague". It may be an unconscious plague ("The Unconscious System Plague: Will Covid-19 Finally Awaken Us?", McMurtry 2020). Intellectuals implicitly legitimate the ruling disorder by an underlying mind-set of acceptable appearances and career advance. They reject or dismiss what is inconsistent with their positional habitus. Academic careers continue to be made by writing on so-and-so on such-and-such about this or that. But what unifies the apparent academic diversity is that the issues remain isolated from the dominant social power and decoupled from any life base. Academic silos pre-set inquiry within narrow technical bounds, and "conspiracy theory" is a standard abuse of deep-structural analysis. While Chomsky likens this "prevailing academic and broader intellectual culture" to "hegemonic culture in the Gramscian sense", Gramsci's hegemony is inadequate to the reality. It is strategic thinking on class dominance which loses Marx's technological-economic foundation, and it has no common life-ground.

Yet what I remember most about Chomsky's essay is his intimation that genocide is a defining American tradition. If by genocide we mean the systematic extermination of a people's way of life, evolved culture, and future life prospects, then genocidal policies have continued from the first peoples through Vietnam and much of Latin America, Palestine, Iraq and Libya today - all with no public comment on this extremest possible "power and powerlessness" imposed on one region after another across the world. Legitimation by silencing is the deep structure. Determinatio est negatio.

Even now, the long US-led process begun by the Reagan administration of multifront destabilisation and destruction of the successful democratic socialism of Yugoslavia remains blinkered out. Across these US-led wars to impose powerlessness and subjugation is the unseen permanent target for genocide - or we should say in light of the facts, eco-genocide. The "big picture" screened out is that the US always attacks collective life infrastructures behind a shifting evil Enemy from "communism" to "Saddam" to "Maduro". But the underlying meaning is taboo, and only the designated Enemy is seen. "Why aren't they cheering?" wondered President Bush Jr. at the height of eco-genocidal bombing of Iraq behind the media-conditioned public hate of Saddam.

Jeff: Could you say more about education as such in the neo-liberal era?

John: Higher education and research have been administratively managed into a corporate agenda since the "global free trade" regime was imposed from 1988 on. Universities have been defunded "to compete in the global market" by lower taxes, patents on university research, and reliance on corporate co-financing. Academic laboratories are leveraged by "corporate partnerships" into commodity research to get funded, faculty must get external money to have labs or graduate students. All must publish in corporately owned journals charging libraries multiplied prices without paying knowledge creators or the institutions funding them. Students are seen as consumers of an investment product for future higher pay with multiplying fees leaving them in life-long debt. Most of the teaching is done by contract employees competing for a secure job from the precariat. University administrations treat their control of academic budgets like equity funds to grow their own CEO-and-bureaucracy salaries and offices under business-dominant boards of governors. Cutbacks are driven by what does not fit into this agenda.

The wider intellectual climate is that there are only diverse narratives and perspectives in the global marketplace, and the truth is what sells. I think public knowledge 
and education are the way ahead. Shared understanding of the spreading incapacitation of our common life bases of higher public research and education is the primary action. Yet we have seen how public knowledge is reversed by President Trump as he spins even a pandemic killing at a ten times higher rate in the US than Canada as "our great success in managing the Chinese virus" while he curtails testing to reduce the infection numbers. However deadly, the repeated big lies displacing science are normalised across domains. Under Trump's watch, public knowledge of every kind has been sweepingly defunded, marketized and outsourced, while environmental and workplace regulations, inspections, and records have been cumulatively eliminated as "red tape" (see "Decoding the Market Destruction of Public Knowledge", McMurtry 2018).

This is our predicament, but so far only surface realities have been engaged. When systematic racism becomes a public issue from videoed police murders in the summer of 2020 , the global free market as the system driver of slavery and racism over 500 years is muted. The biggest scandal of the Covid-19 period in 2020 summer Canada was instead the PM's family work for the charity "WE" before it was picked by the civil service to deliver financial aid to young volunteers and students across Canada. Not reported were non-stop big-oil, mining, bank and corporate lobbies bullying government for their private-profit interests, while countless more billions of public dollars continued to be lost to known tax evasion by the very rich. Throughout the "free market leader of the world" becomes a failed state in public knowledge and response to the Covid-19 virus killing people at the highest per capita rate in the world. Connecting the dots by public education is, in short, still ruled out by "the dominant institutions," while identity politics rising in the streets do not engage the meaning.

Dan: In a recent interview with Jeff (see McMurtry and Klaehn 2020), you defined "life capital" as "all of society's natural resources and support systems, as well as every species and the biodiverse environment and the biosphere itself" [and] "everything and every process that produces more of itself through time without loss and cumulative gain". You identify precisely what some journalists refer to nowadays as the global market for the financialisation and privatisation of nature. Cory Morningstar and Whitney Webb immediately come to mind. Since you have been working on these problems for decades, how would you advise younger scholars and activists to apply the work you've done to regain control over the "life capital" now being vacuumed up by these markets?

John: I think the basic first step is resetting to our common life ground at natural as well as social levels. This is what collective life capital defines, but it is still missing from discussion. It is not just the "privatisation and financialisation of nature," but evolved social life organisation at the same time. Yet no known concept defines this common life ground of our every breath except collective life capital - the value substance of the civil commons. It denotes all that is of reproducible value on earth across the lines of individual death. It is all life capacities that produce more life capacities without loss, from society's health, learning and life security systems to the hydrological cycles of the earth. When these natural and social life foundations are cumulatively despoiled by exponentially multiplying money-demand cycles, the predictable effects are not yet connected nor their common cause understood. This is the missing bottom line as the civil commons and collective life capital are cumulatively dismantled by mutating financial invasion, destabilisation and incapacitation, 
not to mention eco-genocidal wars of aggression. Don't take my word for it. Seek any other concepts to comprehend this common cause and effect.

One might ask, what is so different from the eco-genocidal capitalism of Marx's day? Unlike Marx's period and for 90 years after it, money creation was on the leash of the gold standard as a productive marker and constraint on fractional banking, debt-money creation, and speculative money sequencing. The relationship of finance to the real economy has since been turned upside down. With no gold standard, debt-created money with no limit, no material commodity necessary as middle term, and a globally deregulated money power raiding and exiting societies, ecosystems and labour-forces in nanoseconds, the entire world economy has been financialised with no anchoring value or productive base. At the same time and even more farreaching, technological intensities and scales of power and life destruction are cumulatively ecocidal beyond anything Marx, Keynes or orthodoxy could know. Post gold standard, Wall Street and private transnational syndicates issue and control the funds of the global "casino economy" independently of productive contribution, workers" strike powers, social traditions and controls, national legislation of economic conditions, and the life-carrying capacities of the planet itself. None of this was materially possible until the last 40 years in which these countervailing powers were systematically eliminated as "barriers to the free market" and "necessary market reforms."

Life on earth itself has been destabilised into cumulatively chaotic rounds under totalised extraction, pollution and exhaustion of the rivers, the oceans, the atmosphere, the earth's mantle, the habitats, and the numbers and biodiversity of other species. Sovereign government has been supplanted by captive corporate states stripping funds from their protection. From the scraped ocean bottoms and deep-water plankton and fish to the meltdown of the ice-cap water towers of the continents, there has not only been dispossession of the great majority in capitalist societies, but of the evolved social and natural life support systems of the planet. The awakening is to know that the economy must be re-set to true efficiency - rationing to life necessity which stops the omnicidal system in its tracks.

Jeff and Dan: In what ways do money and financialization influence the moneycapitalist society, and how does this connect with power and legitimations?

John: The private, deregulated, and global private money system is led by Wall Street with US foreign and domestic politics steered behind the scenes. It controls the global debt-service machine in which most states and individuals are increasingly indebted, with $20 \%$ compound interest on the credit cards of those going under including student debtors. It also leads investment in buying futures of water and land as their supply is polluted and depleted by its corporate clients. Wall Street was bailed out of its fraudulent mortgage security scheme in 2008, the greatest fraud in history, with Goldman-Sachs CEO's at the front of government before and after the bankruptcy directing trillions of public money to its biggest banks. This kept its global debt-charges, foreclosures, derivatives, and futures speculation going with the liquidity of public money, and a higher mathematics of concealment to avoid regulation.

The lack of dollar inflation from the trillions poured into Wall Street was managed by squeezing tens of millions of other people into "austerity" of joblessness, life insecurity, and malnutrition. But with no categories for natural or social life capital bases, and an economic model of reversible liquid mechanics from nineteenth-century phys- 
ics, the fatal round is not seen. Thus, Wall-Street-and-company continue to hollow out states, productive enterprises and citizens. Recall Obama's words to Wall Street and company as he lobbied for his re-election in 2012: "My administration is the only thing between you and the pitchforks."

Ironically, private bank-debt bleeding of the real economy is what Benjamin Franklin reported as the primary reason for the 1776 American Revolution - to keep the public-banking "colonial scrip" which brought tax-free prosperity before being ended by the British Currency Act on behalf of the private Bank of England. In little-known social fact, the only system that works for the common life interest is public banking. It begins that way with a public currency protected by government which everyone trusts as a medium of exchange. Without private bank debt-serving charges, the economy can flourish as Pennsylvania's Ben Franklin knew from the "colonial scrip". $\mathrm{He}$ also declined a patent on his Franklin's Stove invention for the advance of knowledge and science - a model of the civil commons. Although Franklin's example has been selected out of US culture, public banking is perhaps the most important collective life capital that society can create.

It is how China came out of nowhere to lead the industrial world by local municipal investment without private debt servicing. Russia rose through public banking before China, and market-society Japan did it through government financial backing of large-scale industrial development and postal banking. Before that, other developed societies relied on non-profit public finance to get there, from Lincoln-led United States before his assassination, and Canada between 1939 and 1973 when the St. Lawrence Seaway and the iconic Canada Health Plan were built. 1973 was the year when the US ended the gold standard to pay for its Vietnam war, and also the year that the Wall Street-led Bank of International Settlements silently ended Canada and other societies' public investments free of accumulating debt charges. Keep your eye now on who holds the debt of government which has skyrocketed in the Covid-19 crisis. It can be held by the national bank or treasury at nominal cost as constitutional public-currency issue. Or it can be private-bank siphons into the life-blood of society for future generations - as in the 2008 public bailout of Wall Street followed by defunding of the public realm.

"Financialisation" is also at work in public infrastructures which are outsourced to private financial interests to draw rent from for the next 25 to 40 years. Every such "public-private partnership" for public services and infrastructure, under whatever name, increases costs, leads to inferior services, and runs down social services and built infrastructures. But corporate-state politicians favour it because the costs can be hidden under "operating expenses" rather than "government spending" which has been publicly stigmatised. "Defence" spending is the granddaddy looter of public wealth. The US now budgets 2000 million dollars on "defence" every day and trillions are unaccounted for or wasted in arms races outsourced to quasi-monopoly corporations, war preparations, illegal embargoes, and increasingly privatised multi-front wars of aggression to "protect the free world". All dots connect, but knowledge of the meaning is excluded from the media and economic models. System legitimation is again by silencing of what contradicts it.

Jeff: I feel it's crucially important, in terms of orienting how we conceptualise and think about power (see Klaehn 2005, 2006a, 2006b, 2010, 2018; Alford et al. 2018; Chomsky 1989; Broudy and Klaehn 2019; Zollmann 2017), to consider how various dimensions of power - material, ideological, political and social - work and are strategically deployed to achieve desired self-interests. In some instances, all these di- 
mensions may be operating in unison, visibly but also often invisibly, within specific time/place contexts, such as, for example, material power converging with institutional power and governmental power, just as ideological power is bound to specific social, political and economic time/place contexts. How do you define "power," John, and what are your thoughts on "power" in relation to public education, specifically within the context of how best to orient our thinking about power today?

John: The key concept here is "power". Although there are "material, ideological, political and social dimensions of power", private money power drives them de facto. It confers the right to demand any product, work or state policy in proportion to how much money one controls through the swinging doors of Wall Street and US government. Material power essentially lies in the forces of production and destruction, and private money power controls them (the meaning of capitalism). Corporate-profit accounting and vehicles then exempt stock owners from liability, avoid taxes, and extract massive hidden public subsidies and loans (basically to grow their private commodity cycles including homicidal weapons). Ideological power? It is primarily borne by the mass media which the same money party owns directly or by buying spaces in self-declared "advertising vehicles". Political power? Money power selects, supports and finances personnel, parties and politicians into electoral office, usually won by candidates and political machines with the most money behind them. Social power? If it is not money-power driven, it is at best the civil commons acting to enable the lives of all or the most deprived. Rising protests and demonstrations against system oppressions, lies, and corruption can be the social immune system at work.

But social power needs to be distinguished from covertly financed uprisings like "the colour revolutions" backed by George Soros in tandem with the CIA and NED (National Endowment for Democracy), or "the dark money" of the Koch brothers behind both the Republican "Tea Party" and ad-space attacks on progressive members of Congress (allowed without legal limit by Citizens United vs. Federal Election Commission nullifying "restrictions on independent expenditures from corporate treasures as violations of the First Amendment"). What is certainly true is the linkage of the "material, political and ideological dimensions of power" to "desired selfinterest". Atomically self-maximising preference governs every sphere of power today except the civil commons, and it is assumed in the academy from contract theory to genetics. Moreover, collective choice forming or sustaining civil commons is not recognised by any contemporary theory or model. Progressive economist-philosopher Amartya Sen's concept of "social choice" in his Nobel-laureate lecture unintentionally demonstrates this fact in his voluminous bibliography confined to aggregates of atomic preferences - essentially "market demand" to whose power governments, electoral systems and textbooks defer as the basis of "free choice". The "public choice theory" of James Buchanan, financed by the Koch brothers, argues that democracy should allow nothing but individual choices, and in double-think turn calls it "public choice theory".

What is not mentioned is that this market freedom extends only so far as money demand, and its power increasingly lies in a few dozen individuals having more than the majority of the world put together. The idea of leaving values as such out of the discussion to consider "material", "ideological", "institutional", "social" and "governmental power" in divided dimensions overlooks the underlying money-value power driving them all. The notion of "power bound to specific social, political and economic time/place" deepens the problem. 
It does not take into account that "specific time/place" has been dispossessed by transnational money power. Its lead global corporations dictate through "free trade" treaties with the force of constitutional law a homogenous regime of state-licensed commodity-cycle extractions for world products which override specific populations and environments, as well as financially directing favourable political representation and media coverage of the transnational corporate agenda within local contexts across cultures and borders. On the other hand, the bonds of civil community inherent in evolved civil commons can also be strongest at "specific social, political and economic time/place" and can join with other districts to become "social power" - the Landless Workers Movement in Brazil, for example, or indigenous uprisings across the world against Big Oil despoliation of life support systems. Poor local communities rising against the privatisation for profit of their water supply have overcome very powerful multinational corporations and client states serving them. These uprisings against the global corporate money power may rise to hundreds a day across the world, but are usually ignored or unknown. Yet the Covid-19 challenge across borders has shown the life-and-death necessity for public finance, programs and action taking into account local and specific places and populations. All of this is civil commons formation on the basis of the collective life capital they protect, even if we do not yet have the categories for it. Such "social power" based in universal life necessities and bonded in community action is ultimately moral in nature, and of historic importance. It has been behind universal life-protective law over centuries - to ban slavery, men-only voting, violent child abuse, death from disemployment, unsafe vehicles, conditions for disease, toxins in consumables, and so on. It is behind all the life enabling programs for clean air and water, sewage plants, green energy, universal literacy, public health, parks, libraries, art, broadcasting and all that private money does not buy. We are now at the visible edge of an unfolding system chaos which demands public re-set to life protective law and collective life capital at every level for the evolution of humanity and the natural world beyond it.

Dan: Can you spell out more what you mean by "values" determining "power"? Your view seems opposed to Marx who conceives "morality" as ideological cover for capitalist class power.

John: Marx's disdain was for moral claims that capitalism is free, optimising and in the interest of all humanity and civilisation. It is these sweeping claims of the capitalist "moral science" that Marx abhors. Yet he failed to see that the laws of capitalism are themselves instituted moral commands whose violation is sternly punished in Old Testament certitude that the "invisible hand" produces the best of possible worlds. In opposition, Marx's description of the capitalist system is morally moved in highlighting its blood-sucking violence, lies, hypocrisy, and mass imposition on the weaker and deprived. What is not understood is that these denunciations logically presuppose a higher norm - in fact, there is Marx's liberative humanism throughout his works (see Structure of Marx's Word-View, McMurtry 1978).

Nihil humani a me alienum puto (Nothing human is alien to me) was his maxim, and Spartacus his first hero in his famous family "confessions". Yet Marx was caught up in the scientism of the era, and so ruling and revolutionary value sets are reified as laws of motion of history. But capitalism mutates. After Marx, it seemed capitalism could adapt to a "mixed economy" of social democratic government reigning in its worst excesses, and this worked from the New Deal to the 1970's. But then from 1980 on, all social and environmental barriers to global capitalism were marked for 
elimination - even the 10-hour day Marx helped to lead - with ever more technological powers to extend and enforce this "new world order" (see Unequal Freedoms: The Global Market as an Ethical System, McMurtry 1998; Value Wars, McMurtry 2002). Marx thought 150 years ago that no moral ground or compass was needed since capitalism would necessarily lead to its own inevitable overthrow. Ironically, he here agrees with orthodoxy on "no alternative" to capitalism and its inevitably optimal outcome. Both are clearly mistaken.

We need to recognise that the meaning of power is not necessarily to serve one's self, class, or nation. It can be the ability to enable and protect human and natural life evolution - to "make the world a better place", as so many claim. In fact, this power to protect life becomes overriding when it is known that capitalism cannot meet the crisis - as in the Covid-19 pandemic with massive public and government commitment to "health first" (see "The Unconscious System Plague: Will Covid-19 Finally Awaken Us?", McMurtry 2020).

In terms of life-value onto-axiology, people work for the common life interest as the evolving moral substance and power of the conscious species of which collective life capital is the common value ground and the civil commons its transgenerational social agency. But since scientific socialism leaves moral purpose behind, "values" are claimed by life-blind forces for whom stock-market rises and lower taxes for the rich are the "moral compass" of "the greatest economy in history". Moral reset to the universal obligations of our common life ground is already moving people beneath words, but the concepts to determine action remain blinkered out.

\section{References}

Alford, Matthew, Daniel Broudy, Jeffery Klaehn, Alan MacLeod, Florian Zollmann. 2019. How the Western Media Supports State Terror - While Millions Die. Peace News 2632-2633:

Available at: $\mathrm{https}$ ://www. filmsforaction.org/articles/the-most-important-article-youll-neverread-how-western-media-support-state-terror-while-millions-die-and-how-this-article-waskilled/

Broudy, Daniel and Jeffery Klaehn. 2019. Chomsky and Herman's Propaganda Model Foretells a Weaponized Facebook. Truthout, June 3. Available at: https://truthout.org/articles/chomsky-and-hermans-propaganda-model-foretells-aweaponized-facebook/

Chomsky, Noam. 1989. Necessary Illusions: Thought Control in Democratic Societies. London: Pluto Press.

Chomsky, Noam. 1967. The Responsibility of Intellectuals. The New York Review of Books, 23 February. Available at: https://www.nybooks.com/articles/1967/02/23/a-specialsupplement-the-responsibility-of-intelle/).

Klaehn, Jeffery. 2018. Media, Power and the Origins of the Propaganda Model: An Interview with Edward S. Herman. Media Theory 2 (2), 95-100. Available at: http://journalcontent.mediatheoryjournal.org/index.php/mt/article/view/60

Klaehn, Jeffery, ed. 2010. The Political Economy of Media and Power. New York: Peter Lang.

Klaehn, Jeffery, ed. 2006a. Bound by Power: Intended Consequences. Montreal: Black Rose Books.

Klaehn, Jeffery. 2006b. The Meta-Program of Power: an interview with John McMurtry. Bound by Power: Intended Consequences, Montreal: Black Rose Books, 105-18.

Klaehn, Jeffery, ed. 2005. Filtering the News: Essays on Herman and Chomsky's Propaganda Model. Montreal: Black Rose Books.

Klaehn, Jeffery, Daniel Broudy, Christian Fuchs, Yigal Godler, Florian Zollmann, Noam Chomsky, Joan Pedro-Carañana, Tom Mills, and Oliver Boyd-Barrett. 2018. Media Theo- 
ry, Public Relevance and the Propaganda Model Today. Media Theory 2 (2): 164-191.

Available at: http://journalcontent.mediatheoryjournal.org/index.php/mt/article/view/67

McMurtry, John. 2020. The Unconscious System Plague: Will Covid-19 Finally Awaken Us?

CounterPunch, 17 April 2020. Available online at

https://www.counterpunch.org/2020/04/17/the-unconscious-system-plague-will-covid-19finally-awaken-us/

McMurtry, John. 2018. Decoding the Market Destruction of Public Knowledge. The European Legacy 24 (1-3): 446-453. DOI: http://doi.org/

McMurtry, John. 2017. 150 Years After Capital: Reading Marx as Life Grounded. Global Research, 31 December 2017. Available online at https://www.globalresearch.ca/150-yearsafter-capital-reading-marx-as-life-grounded/56242

McMurtry, John. 2012. Behind Global System Collapse: The Life-Blind Structure of Economic Reality. Journal of Business Ethics 108 (1): 49-60. DOI: https://doi.org/10.1007/s10551011-1086-4

McMurtry John. 2004a. Understanding Market Theology. In The Invisible Hand and the Common Good. Studies in Economic Ethics and Philosophy, ed. Bernard Hodgson, 151182. Heidelberg: Springer. DOI: https://doi.org/10.1007/978-3-662-10347-0 9

McMurtry John. 2004b. What is Good? What is Bad? The Value of All Values across Time, Place and Theories. In Philosophy and World Problems. Oxford,: EOLSS. Available at https://bsahely.com/2018/06/09/what-is-good-what-is-bad-the-value-of-all-values-throughtime-place-and-theories-by-prof-john-mcmurtryl

McMurtry, John. 2002. Value Wars: The Global Market Versus the Life Economy. London: Pluto Press.

McMurtry, John. 1999/2013. The Cancer Stage of Capitalism: From Crisis to Cure. London: Pluto Press.

McMurtry, John. 1998. Unequal Freedoms: The Global Market As An Ethical System. Toronto: Garamond.

McMurtry, John. 1978. Structure of Marx's Word-View. Princeton, NJ: Princeton University Press.

McMurtry, John and Jeffery Klaehn. 2020. Money Capital vs. Life Capital: The War of Values We Live or Die By. CounterPunch, 16 July 2020. Available online at https://www.counterpunch.org/2020/07/16/money-capital-vs-life-capital-the-war-of-valueswe-live-or-die-byl

Mills, Albert J., Gabrielle Durepos, G., and Elden Wiebe. 2010. Regulating Group Mind. Encyclopedia of Case Study Research. DOI: https://dx.doi.org/10.4135/9781412957397.n291

Noonan, Jeff. 2018. Embodiment and the Meaning of Life. Montreal and Kingston: McGillQueen's University Press.

Zollmann, Florian. 2017. Bringing Propaganda Back Into News Media Studies. Critical Sociology 45 (3): 329-345. Available at: https://doi.org/10.1177/0896920517731134

\section{About the Authors}

John McMurtry earned his PhD in Philosophy at University College London from which developed his definitive The Structure of Marx's World-View (Princeton University Press, 1978). During this period, he began his wide spectrum of post-Marxian articles and books for which he was later elected to the Royal Society of Canada as a "pioneer of social philosophy in ground-breaking articles into unexamined normative infrastructures which oppress human and environmental life." After continuing his life-grounding world travel begun before his $\mathrm{PhD}$, he spent the next decade writing the trio of books beginning with Unequal Freedoms: The Global Market as an Ethical System (1998), The Cancer Stage of Capitalism (1999, revised and expanded 2013) and Value Wars (2002). He was soon after invited by the UNESCO Secretariat to edit and write Philosophy and World Problems in three volumes now available on the web. Active as a public intellectual throughout, McMurty's many articles on public affairs are available on the Internet under author and topic 
search. This tripleC interview continues the deep-structural exploration of everyday life, knowledge and the cultural realm, the planetary environment and the ruling money power with ultimate concern about how health, happiness and the common good can be understood and advanced from within our current global disorder.

Jeffery Klaehn holds a PhD in Communication from the University of Amsterdam and a PhD in Sociology from the University of Strathclyde. His fields of interest include social theory, media, propaganda, power, communication, comics, art, popular culture, and the creative industries. He has edited and co-edited seven books. His research has been published in the European Journal of Communication, International Communication Gazette, Sociology Compass, Journalism Studies, Westminster Papers in Communication and Culture, Media Theory, the Journal of Graphic Novels and Comics, Studies in Comics, and other journals. He resides in Canada. Orcid ID: https://orcid.org/0000-0002-8322-9024

Daniel Broudy is Professor of Rhetoric and Applied Linguistics at Okinawa Christian University. His research includes analysis of prevailing signs and symbols in media and culture that serve to support contemporary political mythologies. He is Co-director of the Working Group on Propaganda and the 9/11 Global "War on Terror"; Associate Researcher in the Organisation for Propaganda Studies; and Associate Editor for Frontiers in Communication. His latest book is the co-authored Okinawa Under Occupation: McDonaldization and Resistance to Neoliberal Propaganda (Palgrave 2017). 